\title{
Nitrite oxidation in the upper water column and oxygen minimum zone of the eastern tropical North Pacific Ocean
}

\author{
J Michael Beman ${ }^{1}$, Joy Leilei Shih ${ }^{2}$ and Brian N Popp ${ }^{2}$ \\ ${ }^{1}$ Life and Environmental Sciences and Sierra Nevada Research Institute, University of California, Merced, \\ Merced, CA, USA and ${ }^{2}$ School of Ocean and Earth Science and Technology, University of Hawai'i, Honolulu, \\ Hawaii
}

\begin{abstract}
Nitrogen $(\mathrm{N})$ is an essential nutrient in the sea and its distribution is controlled by microorganisms. Within the $\mathrm{N}$ cycle, nitrite $\left(\mathrm{NO}_{2}^{-}\right)$has a central role because its intermediate redox state allows both oxidation and reduction, and so it may be used by several coupled and/or competing microbial processes. In the upper water column and oxygen minimum zone (OMZ) of the eastern tropical North Pacific Ocean (ETNP), we investigated aerobic $\mathrm{NO}_{2}^{-}$oxidation, and its relationship to ammonia $\left(\mathrm{NH}_{3}\right)$ oxidation, using rate measurements, quantification of $\mathrm{NO}_{2}^{-}$-oxidizing bacteria via quantitative PCR (QPCR), and pyrosequencing. ${ }^{15} \mathrm{NO}_{2}^{-}$oxidation rates typically exhibited two subsurface maxima at six stations sampled: one located below the euphotic zone and beneath $\mathrm{NH}_{3}$ oxidation rate maxima, and another within the $\mathrm{OMZ} .{ }^{15} \mathrm{NO}_{2}^{-}$oxidation rates were highest where dissolved oxygen concentrations were $<5 \mu \mathrm{M}$, where $\mathrm{NO}_{2}^{-}$accumulated, and when nitrate $\left(\mathrm{NO}_{3}^{-}\right)$reductase genes were expressed; they are likely sustained by $\mathrm{NO}_{3}^{-}$reduction at these depths. QPCR and pyrosequencing data were strongly correlated $\left(r^{2}=0.79\right)$, and indicated that Nitrospina bacteria numbered up to $9.25 \%$ of bacterial communities. Different Nitrospina groups were distributed across different depth ranges, suggesting significant ecological diversity within Nitrospina as a whole. Across the data set, ${ }^{15} \mathrm{NO}_{2}^{-}$oxidation rates were decoupled from ${ }^{15} \mathrm{NH}_{4}^{+}$oxidation rates, but correlated with Nitrospina $\left(r^{2}=0.246, P<0.05\right)$ and $\mathrm{NO}_{2}^{-}$concentrations $\left(r^{2}=0.276, P<0.05\right)$. Our findings suggest that Nitrospina have a quantitatively important role in $\mathrm{NO}_{2}^{-}$oxidation and $\mathrm{N}$ cycling in the ETNP, and provide new insight into their ecology and interactions with other N-cycling processes in this biogeochemically important region of the ocean.
\end{abstract}

The ISME Journal (2013) 7, 2192-2205; doi:10.1038/ismej.2013.96; published online 27 June 2013

Subject Category: Geomicrobiology and microbial contributions to geochemical cycles

Keywords: nitrification; nitrite oxidation; nitrospina; oxygen minimum zone; pyrosequencing

\section{Introduction}

Nitrogen $(\mathrm{N})$ is a required nutrient for all organisms and limits primary production across large areas of the ocean (Mills et al., 2004). Although $\mathrm{N}$ is present in many different chemical forms in the sea, dissolved nitrite $\left(\mathrm{NO}_{2}^{-}\right)$alone may be used by microorganisms either as a reductant (under aerobic conditions) or oxidant (under anaerobic conditions) owing to its intermediate redox state. In the aerobic ocean, $\mathrm{NO}_{2}^{-}$is oxidized to nitrate $\left(\mathrm{NO}_{3}^{-}\right)$by $\mathrm{NO}_{2}^{-}$-oxidizing bacteria (NOB); this constitutes the second step of nitrification and is expected to be

Correspondence: JM Beman, Life and Environmental Sciences and Sierra Nevada Research Institute University of California, Merced, 5200 North Lake Road, Merced 95343, CA, USA.

E-mail: jmbeman@gmail.com

Received 18 December 2012; revised 23 April 2013; accepted 17 May 2013; published online 27 June 2013 tightly coupled to the first step, oxidation of ammonia $\left(\mathrm{NH}_{3}\right)$ by $\mathrm{NH}_{3}$-oxidizing bacteria and $\mathrm{NH}_{3}$-oxidizing Archaea. No single organism is known to carry out both steps of nitrification. Costa et al. (2006) argue that this reflects optimization of pathway length to maximize energy production, and that because $\mathrm{NO}_{2}^{-}$oxidation is energetically less favorable, it must occur more rapidly than $\mathrm{NH}_{3}$ oxidation and consume $\mathrm{NO}_{2}^{-}$nearly instantaneously. However the coupling between these groups is fundamentally unstable: Graham et al. (2007) demonstrated that perturbation of $\mathrm{NH}_{3}$ oxidation in bioreactors lead to chaotic behavior among NOB, and evidence for such temporal decoupling in the ocean was observed off southern California (Beman et al., 2010). $\mathrm{NH}_{3}$ and $\mathrm{NO}_{2}^{-}$oxidation can also be decoupled spatially; light is thought to directly or indirectly inhibit $\mathrm{NH}_{3}$-oxidizing Archaea, $\mathrm{NH}_{3}$-oxidizing bacteria and NOB to varying degrees, with NOB being more sensitive (reviewed by Lomas 
and Lipschultz (2006). This may contribute to the accumulation of $\mathrm{NO}_{2}^{-}$at the base of the euphotic zone-a widespread feature known as the primary $\mathrm{NO}_{2}^{-}$maximum (PNM). Although prevailing evidence indicates that PNM primarily results from incomplete phytoplankton reduction of $\mathrm{NO}_{3}^{-}$ (Lomas and Lipschultz, 2006, Beman et al., 2012), this remains uncertain because direct quantitative comparisons between $\mathrm{NH}_{3}$ and $\mathrm{NO}_{2}^{-}$oxidation, and the microorganisms involved, are rare (Ward et al., 1989a, Lipschulz et al., 1990).

Of particular relevance is the recent discovery that marine Thaumarchaeota (formerly marine group 1 Crenarchaeota) oxidize $\mathrm{NH}_{3}$ (reviewed by Francis et al. (2007); these organisms number up to $10^{28}$ cells in the ocean (Karner et al., 2001) and even modest per cell rates of archaeal $\mathrm{NH}_{3}$ oxidation imply substantial global $\mathrm{N}$ turnover. In fact, recent studies indicate that $\mathrm{NH}_{3}$ oxidation occurs more rapidly and over a broader depth range than previously appreciated (Yool et al., 2007, Beman et al., 2008, Lam et al., 2009, Santoro et al., 2010, Beman et al., 2012). $\mathrm{A} \mathrm{NO}_{2}^{-}$rarely accumulates in the ocean (discussed above), this necessitates a corresponding sink for $\mathrm{NO}_{2}^{-}$. Mincer et al. (2007) proposed that correlation between $\mathrm{NH}_{3}$-oxidizing Archaea and relatives of known $\mathrm{NO}_{2}^{-}$-oxidizing Nitrospina bacteria is evidence of metabolic coupling; these groups showed similar distributions in both Monterey Bay and the North Pacific Subtropical Gyre. More recently, Füssel et al. (2012) reported that Nitrospina numbered up to $5.4 \%$ of microbial cells and were detected where $\mathrm{NO}_{2}^{-}$was oxidized in the oxygen minimum zone (OMZ) along the Namibian coast. This included depths were dissolved oxygen (DO) concentrations were extremely low, indicating that $\mathrm{NO}_{2}^{-}$oxidation persists even under low DO. In fact, $\mathrm{NO}_{2}^{-}$-based metabolism is central in the world's OMZs (Francis et al., 2007; Wright et al., 2012), where DO concentrations fall below $20 \mu \mathrm{M}$ because of microbial respiration (Paulmier and Ruiz-Pino, 2009). The accumulation of $\mathrm{NO}_{2}^{-}$within OMZs is a diagnostic of anaerobic $\mathrm{N}$ and sulfur cycling (Ulloa et al., 2012), and among the processes that use $\mathrm{NO}_{2}^{-}$ as an oxidant under these conditions, anammox and denitrification lead to gaseous $\mathrm{N}$ loss from the ocean (Lam and Kuypers, 2011). However, the source of $\mathrm{NO}_{2}^{-}$that fuels these processes is poorly constrained. $\mathrm{NH}_{3}$ oxidation may contribute $\mathrm{ca} .50 \%$ of $\mathrm{NO}_{2}^{-}$supply to anammox in the Black Sea (Lam et al., 2007), whereas $\mathrm{NO}_{3}^{-}$reduction coupled to anammox was most important (at least $67 \%$ of $\mathrm{NO}_{2}^{-}$ demand) in the eastern tropical South Pacific (ETSP) OMZ (Lam et al., 2009), and Ward et al. (2009) demonstrated that conventional denitrification was dominant in the Arabian Sea.

The eastern tropical North Pacific Ocean (ETNP) is the largest oceanic OMZ (Paulmier and Ruiz-Pino, 2009), and so has an important role in oceanic-and global $-\mathrm{N}$ cycling. Annually, $26 \mathrm{Tg}$ of dissolved N is converted to gaseous forms in the ETNP (DeVries et al., 2012) via microbial processes that require oxidized N. Our work and that of others has also identified relatively high rates of $\mathrm{NH}_{3}$ oxidation in the ETNP (Ward and Zafiriou, 1988, Sutka et al., 2004, Beman et al., 2008, 2012); yet $\mathrm{NO}_{2}^{-}$oxidation has not been previously measured in this region. As $\mathrm{NO}_{2}^{-}$oxidation can persist under $<1 \mu \mathrm{M}$ DO, NOB may directly compete with other organisms for $\mathrm{NO}_{2}^{-}$ in OMZs (Lipschultz et al., 1990, Füssel et al., 2012); in the ETNP OMZ, the accumulation of $\mathrm{NO}_{2}^{-}$and its isotopic composition suggest that $\mathrm{NO}_{3}^{-}$may be continually reduced and reoxidized through dynamic $\mathrm{N}$ and $\mathrm{NO}_{2}^{-}$cycling (Casciotti and McIlvin, 2007). Adding to this complexity, OMZs are expanding as a consequence of climate change (Stramma et al., 2008, Keeling et al., 2010), potentially altering the rates and distribution of $\mathrm{N}$ transformations in the water column (Gilly et al., 2013). In the ETNP, N loss rates have varied severalfold over the past few decades in response to variations in the DO (Deutsch et al., 2011). Placing quantitative bounds on microbially driven biogeochemical processes occurring in OMZs-and specifically the ETNP-is therefore essential.

We quantified $\mathrm{NO}_{2}^{-}$oxidation rates and $\mathrm{NOB}$ distributions across an oceanographic transect through northern portions of the ETNP and the southern Gulf of California (GOC). Using an in situ floating array and stable isotope tracer, ${ }^{15} \mathrm{NO}_{2}^{-}$ oxidation rates were measured at high resolution with depth; NOB were quantified using real-time quantitative PCR (QPCR) and next-generation pyrosequencing of bacterial communities in corresponding DNA samples. This parallels our work on $\mathrm{NH}_{3}$ oxidation for the same stations and depths (Beman et al., 2012). Dual study of these processeswhich presumably are biogeochemically coupled, and together constitute nitrification-are rare in the literature. We compared ${ }^{15} \mathrm{NO}_{2}^{-}$oxidation rate profiles with ${ }^{15} \mathrm{~N}$-labeled ammonium $\left({ }^{15} \mathrm{NH}_{4}^{+}\right)$oxidation rates, depth profiles of NOB and key environmental factors such as $\mathrm{NO}_{2}^{-}$concentrations and $\mathrm{DO}$ concentrations.

\section{Materials and methods}

\section{Sampling and biogeochemical measurements}

Samples were collected in July and August of 2008 aboard the $R / V$ New Horizon; seven stations were occupied for several days each. A Seabird Electronics (Bellevue, WA, USA) SBE 9 conductivitytemperature-depth sensor package equipped with additional sensors was used to measure conductivity, temperature, depth, DO concentrations, chlorophyll fluorescence, light transmission and photosynthetically active radiation. Water samples were collected using $10 \mathrm{l}$ polyvinyl chloride bottles deployed on the conductivity-temperature-depth rosette; samples for nutrient measurements and Winkler titrations were typically collected on the 
first cast and analyzed within hours of collection to characterize the chemical structure of the water column. We selected depths for rate measurements and collection of DNA samples based primarily on nutrient concentrations: 1-3 depths above the primary $\mathrm{NO}_{2}^{-}$and $\mathrm{NH}_{4}^{+}$maxima were sampled, followed by $5-7$ depths spaced every $5 \mathrm{~m}$ and several additional depths spaced every $10-20 \mathrm{~m} .{ }^{15} \mathrm{NO}_{2}^{-}$ oxidation rates were measured at each depth on a free-floating array (see below), and DNA samples were collected at the same depths (see below). Water samples for rate measurements and DNA samples were collected on the same cast at all stations.

Details of biogeochemical measurements are provided in Beman et al. (2012). Briefly, oxygen concentrations were measured using a SBE oxygen sensor and corrected on the basis of Winkler titrations ( $r^{2}=0.997$ for 187 samples for the cruise). Winkler-corrected SBE oxygen data are shown for the casts where rate and DNA samples were collected. $\mathrm{NH}_{4}^{+}$concentrations were measured using the fluorometric method of Holmes et al. (1999), and $\mathrm{NO}_{2}^{-}$and $\mathrm{NO}_{3}^{-}$concentrations were measured using standard colorimetric techniques (Strickland and Parsons, 1972); $\mathrm{NO}_{3}^{-}$was reduced to $\mathrm{NO}_{2}^{-}$ with cadmium for measurement. $r^{2}$ for standard curves were: 0.996-0.999 (oxygen measurements), 0.959-0.999 $\left(\mathrm{NH}_{4}^{+}\right.$measurements) and 0.993-0.999 ( $\mathrm{NO}_{2}^{-}$and $\mathrm{NO}_{3}^{-}$measurements).

\section{In situ free-floating array}

We deployed a free-floating array to mimic in situ conditions for ${ }^{15} \mathrm{NO}_{2}^{-}$oxidation rate measurements (Beman et al., 2012). ${ }^{15} \mathrm{NO}_{2}^{-}$oxidation was measured via addition of ${ }^{15} \mathrm{~N}$-labeled $\mathrm{NO}_{2}^{-}$to sample bottles suspended at multiple depths in the water column; water samples were collected into $250 \mathrm{ml}$ polycarbonate bottles in the dark using silicone tubing, samples were overfilled by three volumes to avoid oxygen contamination, chilled ${ }^{15} \mathrm{~N}$-labeled $\mathrm{NaNO}_{2}$ was added and bottles were sealed. Bottles were attached to the array immediately before deployment at dawn, and the array was deployed for $c a$. $24 \mathrm{~h}$ under in situ temperature and light conditions. Our deepest array-based incubations were placed at $160 \mathrm{~m}$ depth, and samples collected from depths $>160 \mathrm{~m}$ were incubated onboard the ship at $12^{\circ} \mathrm{C}$ in the dark within temperature-controlled incubators; this includes 18 samples reported here. Following array recovery, samples were filtered through $0.2 \mu \mathrm{m}$ syringe filters, collected in $50 \mathrm{ml}$ high-density polyethylene bottles, residual ${ }^{15} \mathrm{NO}_{2}^{-}$was removed (see below) and samples frozen at $-20^{\circ} \mathrm{C}$ until analysis at the University of Hawaii.

\footnotetext{
${ }^{15} \mathrm{NO}_{2}^{-}$oxidation rate measurements

${ }^{15} \mathrm{NO}_{2}^{-}$oxidation rates were measured by adding 98 atom percent (atom\%) ${ }^{15} \mathrm{NO}_{2}^{-}$to a final concentration of 48-192 $\mathrm{nmoll}^{-1}$ (depending on in situ $\mathrm{NO}_{2}^{-}$
}

concentrations) and measuring the accumulation of ${ }^{15} \mathrm{~N}$ label in the $\mathrm{NO}_{3}^{-}$pool after incubation for $\sim 24 \mathrm{~h}$; excess ${ }^{15} \mathrm{NO}_{2}^{-}$was removed using methods modified from Granger and Sigman (2009). Upon recovery of samples from the in situ array, sulfamic acid $\left(\sim 8-10 \mu \mathrm{l} \mathrm{ml}^{-1}\right)$ was added, the samples were shaken and allowed to sit for $>5 \mathrm{~min}$, and then samples were neutralized by adding $\mathrm{NaOH}(4 \mathrm{M}$, $\sim 11 \mu \mathrm{lml} \mathrm{ml}^{-1}$ ) before storing frozen $\left(-20^{\circ} \mathrm{C}\right)$ until analysis. The efficiency of ${ }^{15} \mathrm{NO}_{2}^{-}$removal using this method was tested in the laboratory and our results indicated a minor amount of ${ }^{15} \mathrm{NO}_{3}^{-}$was present after the sulfamic acid treatment, most likely owing to a small quantity of ${ }^{15} \mathrm{NO}_{3}^{-}$contamination in $\mathrm{K}^{15} \mathrm{NO}_{2}$ (see Olson, 1981; Ward, 1987; Lipschultz et al., 1990). However, the amount of ${ }^{15} \mathrm{~N}$ label remaining was not significantly higher at concentrations of ${ }^{15} \mathrm{NO}_{2}^{-}<200 \mathrm{nmoll}^{-1}$, and so does affect our rate calculations.

The $\delta^{15} \mathrm{~N}$ value of $\mathrm{N}_{2} \mathrm{O}$ produced from $\mathrm{NO}_{3}^{-}$using the denitrifier method (Sigman et al., 2001) was measured using methods described in Popp et al. (1995) and Dore et al. (1998). Briefly, $\mathrm{N}_{2} \mathrm{O}$ produced from $\mathrm{NO}_{3}^{-}$was transferred from a reaction vial, cryofocused, separated from other gases using a 0.32-mm inner diameter $25 \mathrm{~m} \times 5 \mu \mathrm{m}$ CP-PoraBOND Q (Agilent Technologies, Santa Clara, CA, USA) capillary column at room temperature and introduced into the ion source of a MAT252 mass spectrometer through a modified GC-C I interface (Thermo Scientific, Bremen, Germany). Isotopic reference materials (United States Geological Survey32, National Institute of Standards and Technology3 and University of Hawaii $\mathrm{NaNO}_{3}$ ) bracketed every nine samples and $\delta^{15} \mathrm{~N}$ values measured online were linearly correlated $\left(r^{2}=0.979\right)$ with accepted reference material $\delta^{15} \mathrm{~N}$ values. Accuracy and precision were further evaluated by multiple analyses of a sodium $\mathrm{NO}_{3}^{-}$solution for which the $\delta^{15} \mathrm{~N}$ value of the solid $\mathrm{NaNO}_{3}$ (that is, University of Hawaii $\mathrm{NaNO}_{3}$ ) had been previously determined using an online carbon-N analyzer coupled with an isotope ratio mass spectrometer (ConFlo II Delta-Plus; Thermo Scientific), and were found to be $< \pm 0.5 \%$ $\left( \pm 0.00018\right.$ atom $\left.\%{ }^{15} \mathrm{~N}\right)$ for samples containing $>2.5 \mathrm{nmol}$ of $\mathrm{NO}_{3}^{-}$.

Initial atom $\%$ enrichment of the substrate at the beginning of the experiment $\left(n \mathrm{NO}_{2}^{-}\right.$, see Equation (1)) was calculated by isotope mass balance based on $\mathrm{NO}_{2}^{-}$concentrations, assuming that the ${ }^{15} \mathrm{~N}$ activity of unlabeled $\mathrm{NO}_{2}^{-}$was 0.3663 atom $\%{ }^{15} \mathrm{~N}$. Rates of ${ }^{15} \mathrm{NO}_{2}^{-}$oxidation $\left({ }^{15} \mathrm{R}_{o x}\right)$ were calculated using Equation (1) from Ward et al. (1989b):

$$
{ }^{15} \mathrm{R}_{O X}=\frac{\left(\mathrm{n}_{t}-\mathrm{n}_{O N O_{3}^{-}}\right) \times\left[N O_{3}^{-}\right]}{\left(\mathrm{n}_{N O_{2}^{-}}\right) \times t}
$$

where $n_{\mathrm{t}}$ is the atom\% $\%{ }^{15} \mathrm{~N}$ in $\mathrm{NO}_{3}^{-}$measured at time $t, \mathrm{n}_{\text {ONO3 }}$ is the measured atom\% $\%{ }^{15} \mathrm{~N}$ of unlabeled $\mathrm{NO}_{3}^{-},\left[\mathrm{NO}_{3}^{-}\right]$is the concentration of the $\mathrm{NO}_{3}^{-}$pool 
and $\mathrm{n}_{\mathrm{NO}}^{-}$is the exponential average atom $\%$ of $\mathrm{NO}_{2}^{-}$ over time $t . \mathrm{n}_{\mathrm{NO}^{-}}$was calculated based on ambient $\mathrm{NO}_{2}^{-}$concentrations and atom\% (assumed to be 0.3663 ), added ${ }^{15} \mathrm{~N}$-labeled $\mathrm{NO}_{2}^{-}$, and measured ${ }^{15} \mathrm{NH}_{4}^{+}$oxidation rates (producing unlabeled $\mathrm{NO}_{2}^{-}$) reported by Beman et al. (2012).

\section{DNA and RNA extraction}

At each depth, $4 \mathrm{l}$ of seawater was collected from the conductivity-temperature-depth rosette and divided into two sets of 2-l samples, which were then filtered through separate $25 \mathrm{~mm}$ diameter $0.2 \mu \mathrm{m}$ Suppor filters (Pall Corporation, Port Washington, NY, USA) using a peristaltic pump. Filters were flash-frozen in liquid $\mathrm{N}$ and stored at $-80^{\circ} \mathrm{C}$ until DNA and RNA extraction, with one set of filters dedicated to each. Details of DNA extraction were reported in Beman et al. (2012). Filters for RNA extraction were frozen in RLT buffer with betamercaptoethanol added (Qiagen, Valencia, CA, USA), and RNA was extracted using the Qiagen RNeasy kit following Church et al. (2005) but with the following modifications: tubes containing filters, glass beads and buffer were first agitated for $80 \mathrm{~s}$ on a FastPrep machine (MP Biomedicals, Solon, OH, USA) at setting 5.5; each sample and an equal volume of $70 \%$ ethanol solution was then bound to the RNeasy spin column, and purified and eluted following the manufacturer's instructions. We used Turbo DNase (Ambion, Life Technologies Corporation, Carlsbad, CA, USA) to remove carry-over DNA, and samples were treated with $10 \%$ DNase buffer and $5 \%$ DNase for $20 \mathrm{~min}$ at $37^{\circ} \mathrm{C}$.

Complementary DNA was generated from extracted RNA using the Invitrogen SuperScript III Reverse Transcriptase kit (Life Technologies Corporation), following the manufacturer's instructions. In brief, ten microliters of RNA extract, $1 \mu \mathrm{l}$ each of random hexamers and $1 \mu \mathrm{l} 10 \mathrm{~mm}$ dNTPs were incubated at $65{ }^{\circ} \mathrm{C}$ for $5 \mathrm{~min}$, and then placed on ice for $1 \mathrm{~min}$; samples were then incubated with $10 \mu \mathrm{l}$ of complementary DNA synthesis mix $(2 \mu \mathrm{l}$ $10 \times$ reverse transcriptase buffer, $4 \mu \mathrm{l} 25 \mathrm{mM} \mathrm{MgCl}_{2}$, $2 \mu \mathrm{l} 0.1 \mathrm{M}$ dithiothreitol, $1 \mu \mathrm{l}$ RNase OUT (40 U $\mu \mathrm{l}^{-1}$ ) and $1 \mu \mathrm{l}$ SuperScript III Reverse Transcriptase) at $25{ }^{\circ} \mathrm{C}$ for $10 \mathrm{~min}$, then $55^{\circ} \mathrm{C}$ for $50 \mathrm{~min}$, and the reverse transcriptase reaction was terminated at $85^{\circ} \mathrm{C}$ for 5 min. Remaining RNA was removed through incubation with RNase $\mathrm{H}$ at $37^{\circ} \mathrm{C}$ for $20 \mathrm{~min}$.

\section{Quantitative PCR}

QPCR assays were performed on a Stratagene MX3005P (Agilent Technologies), using the following reaction chemistry: $12.5 \mu \mathrm{l}$ SYBR Premix F (Epicentre Biotechnologies, Madison, WI, USA), $2 \mathrm{mM} \mathrm{MgCl}_{2}, 0.4 \mu \mathrm{M}$ of each primer, 1.25 units AmpliTaq polymerase (Applied Biosystems, Life Technologies Corporation, Carlsbad, CA, USA), $40 \mathrm{ng} \mu \mathrm{l}^{-1}$ bovine serum albumin and $1 \mathrm{ng}$ DNA in a final volume of $25 \mu \mathrm{l}$. 16S rRNA genes from Nitrospina were amplified in triplicate using the primers NitSSU_130 F (5'-GGGTGAGTAACAC GTGAATAA-3') and NitSSU_282 R (5'-TCAG GCCGGCTAAMCA-3'; Mincer et al., 2007). Coefficient of variations of triplicate QPCR reactions averaged $5 \%$. Cycling conditions were modified from Mincer et al. (2007): the total number of cycles was reduced from 50 to 30 , and the length of the detection step was increased from 1 to $7 \mathrm{~s}$. The partial 16S rRNA sequence from the uncultured marine Nitrospinaceae bacterium recovered on BAC EB080L20_F04 was used as a QPCR standard; this sequence was synthesized at Blue Heron Biotechnologies (Bothell, WA, USA) and used in tenfold dilutions from $10^{7}$ to $10^{2} 16 \mathrm{~S}$ rRNA genes per $\mu \mathrm{l}$ to generate standard curves $\left(r^{2}=0.987-0.994\right)$. narG and napA assays followed Lam et al. (2009) and were used to screen select complementary DNA samples (see text); negative controls did not exhibit amplification.

\section{Pyrosequencing}

DNA samples collected at all depths at stations 1-6 were sequenced using Titanium chemistry on the Roche 454 (Branford, CT, USA) FLX platform at Research and Testing Laboratories. No samples from station 7 were sequenced. Bacteria-specific primers 27F (5'-GAGTTTGATCNTGGCTCAG-3') and 519R (5'-GWNTTACNGCGGCKGCTG-3'; $\quad$ Engelbrektson et al., 2010) modified with additional degeneracies (Ns in primer sequence) were used to amplify a portion of the bacterial 16S rRNA gene. Relevant linkers were attached to primers, as were eight-base barcodes (Hamady et al., 2008) used to sort individual samples; for the 60 samples, we recovered 714245 sequences with a median read length of $475 \mathrm{bp}$. We used the approach of Huse et al. (2007) that is commonly used in the literature for quality control (Brown et al., 2009; Galand et al., 2009). Using the program mothur (http://www.mothur.org; Schloss et al. 2009), we discarded sequences: $> \pm 100$ bp from the median sequence length, containing any ambiguous bases, containing homopolymers $>8 \mathrm{bp}$, of $<25$ average quality score, and that did not exactly match the forward primer and barcode sequence. The final criterion is where most (21\% of all sequences) sequences were removed. (We did not screen sequences based on the reverse primer, as some of the reads are high quality sequences that did not extend to the reverse primer). In total, 282030 sequences did not meet quality control criteria and were excluded from subsequent analyses.

Bacterial 16S rRNA sequences were aligned to the Greengenes alignment (DeSantis et al., 2006) in mothur. The alignment was optimized to the start position and we discarded sequences starting after the position that $95 \%$ of the sequences start; the alignment was then manually curated to remove misaligned sequences $(n=25)$. Community 
composition of individual samples was determined by classification of $16 \mathrm{~S}$ rRNA sequences based on the ARB SILVA data set (Pruesse et al., 2007) in mothur, and data are reported for a consensus confidence threshold of $65 \%$. The 8997 Nitrospina 16S rRNA gene sequences identified here were clustered into operational taxonomic units (OTUs) based on $97 \%$ sequence identity, and sequences from the 476 OTUs have been deposited in GenBank under accession numbers KC774803-KC775278. We generated representative sequences for each OTU using the get.oturep command in mothur, and BLASTed these sequences against the Genbank nr/ nt nucleotide database using blastn and default parameters (database accessed 8 March 2013).

\section{Data analysis}

Oceanographic data were visualized in Ocean Data View (http://www.odv.awi.de/). To compute the abundance of different Nitrospina OTUs, we used QPCR data and the proportion of Nitrospina sequences that were affiliated with the different OTUs; that is, the OTU abundance equals the QPCR-based Nitrospina abundance at a particular depth, multiplied by the fraction of sequences drawn from a particular Nitrospina OTU in proportion to the total number of Nitrospina sequences recovered at that depth. This approach is similar to using the relative abundance of terminal-restriction fragment-length polymorphism OTUs and cell counts to examine patterns in SAR11 ecotypes (Carlson et al., 2009), but in this case we focus on Nitrospina and use pyrosequencing and QPCR data. All statistical analyses were conducted in MATLAB version 7.6.0 (R2008a; MathWorks, Natick, MA, USA).

\section{Results and discussion}

\section{Oceanographic variability}

The OMZ of the ETNP extends from the west coast of North America thousands of kilometers across the Pacific Ocean (Figure 1). Low oxygen waters also

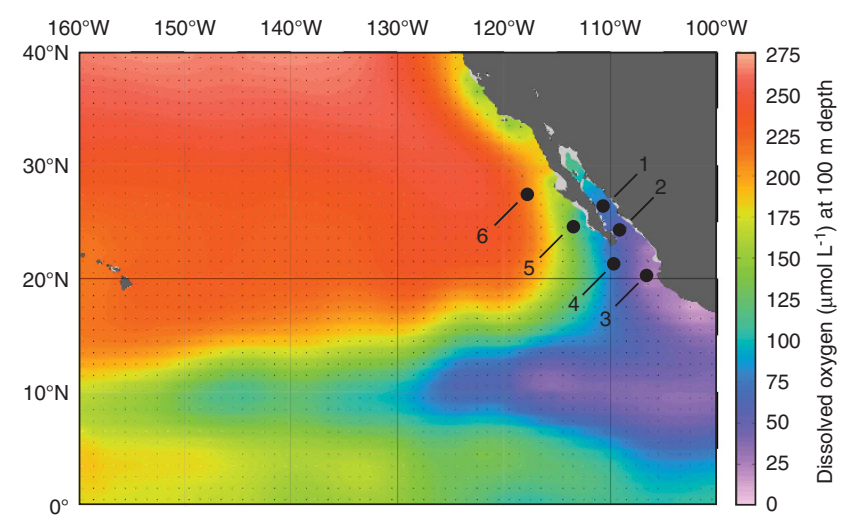

Figure 1 Cruise track in the GOC and ETNP. Station locations are plotted on DO concentrations $(\mu \mathrm{M})$ at $100 \mathrm{~m}$ depth from the World Ocean Atlas in Ocean Data View. extend into the GOC and we sampled a series of six stations in the GOC and ETNP; station 1 was located in the Carmen Basin of the GOC, station 2 was located near the mouth of the GOC and station 3 was located in the core of the ETNP OMZ (Figure 1; Supplementary Table S1), where oxygen concentrations declined rapidly with depth and dropped to $20 \mu \mathrm{mol} \mathrm{kg}{ }^{-1}$ by $111 \mathrm{~m}$ (Figure 2o). Three additional stations extended north from the tip of Baja California Sur (station 4) to several hundred kilometers off the coast of northern Baja (Figure 1). (A seventh station sampled for ${ }^{15} \mathrm{NH}_{4}^{+}$oxidation rates (Beman et al., 2012) was not sampled for ${ }^{15} \mathrm{NO}_{2}^{-}$oxidation). General trends in temperature, DO and nutrient concentrations were reported previously (Beman et al., 2012): sea surface temperatures increased from north to south, reaching nearly $30^{\circ} \mathrm{C}$ at station 3 ; the $\mathrm{OMZ}$ also broadened and shoaled to the south and DO reached lower absolute values (Figures 2 and $3 \mathrm{e}, \mathrm{j}, \mathrm{o}$ ). The concentrations of $\mathrm{NH}_{4}^{+}$and $\mathrm{NO}_{2}^{-}$were highest at discrete depths in the water column (Figures 2 and $3 \mathrm{~d}, \mathrm{i}, \mathrm{n})$. These depths were greater at stations 3 and 6 and relatively shallow at stations 1 and 4, with stations 2 and 5 being intermediate. The PNM was offset from the $\mathrm{NH}_{4}^{+}$maximum by $5-10 \mathrm{~m}$ at stations 3 and 4 , and was colocated with the $\mathrm{NH}_{4}^{+}$maximum at stations 1, 2 and 5 (Figures 2 and 3). Prominent secondary $\mathrm{NO}_{2}^{-}$maxima were observed at stations 2 and 3 in OMZ waters, and $\mathrm{NO}_{2}^{-}$concentrations at these depths were an order of magnitude greater than that in the PNM (up to $4.2 \mu \mathrm{mol}^{-1}$ at stations 2 and 3 ; Figures 2i, n and 4a).

\section{$\mathrm{NO}_{2}^{-}$oxidation rates and $\mathrm{NH}_{3}$ oxidation rates}

Within this oceanographic context, we found that ${ }^{15} \mathrm{NO}_{2}^{-}$oxidation rates varied strongly with depth and from station to station (Figures 2 and $3 \mathrm{~b}, \mathrm{~g}, \mathrm{l}$ ). They typically exhibited peaks at the base of the euphotic zone, decreased slightly with depth, and in some cases, increased again on the edge of the OMZ. Maximum rates at each station ranged from $44.5-213 \mathrm{nmoll}^{-1} \mathrm{~d}^{-1}$, and minimum rates ranged from undetectable to $50.4 \mathrm{nmoll}^{-1} \mathrm{~d}^{-1}$ across stations. These values are in line with previous studies that have measured rates of $0-600 \mathrm{nmoll}^{-1}$ $\mathrm{d}^{-1}$ across different regions of the ocean (Ward, 1987, Lipschultz et al., 1990; Dore and Karl, 1996; Bianchi et al., 1999; Clark et al., 2008; Füssel et al., 2012). Higher rates have typically been observed in OMZs and other productive regions of the oceansuch as the ETSP, in the Benguela upwelling region and in the Southern California Bight (Ward, 1987; Lipschultz et al., 1990; Füssel et al., 2012)—than within oligotrophic regions (Dore and Karl, 1996; Bianchi et al., 1999; Clark et al., 2008). Overall, ${ }^{15} \mathrm{NO}_{2}^{-}$oxidation rates were correlated with $\mathrm{NO}_{2}^{-}$ concentrations $\left(r^{2}=0.344, P<0.05\right.$; Figure 4a) in the GOC and ETNP, and relationships between rates and $\mathrm{NO}_{2}^{-}$were strongest at stations 2 and 5 (Table 1). 
Nitrospina 16S rRNA

genes $\left(10^{3} \mathrm{~mL}^{-1}\right)$

Nitrospina (\% of

sequence libraries)

${ }^{15} \mathrm{NO}_{2}^{-}$oxidation

rate $\left(\mathrm{nmol} \mathrm{L}-1 \mathrm{~d}^{-1}\right)$

${ }^{15} \mathrm{NH}_{4}+$ oxidation

rate $\left(\mathrm{nmol} \mathrm{L}{ }^{-1} \mathrm{~d}^{-1}\right)$

Nitrite (nM)

Ammonium (nM)

Dissolved oxygen

$\left(\mu \mathrm{mol} \mathrm{kg}{ }^{-1}\right.$ )
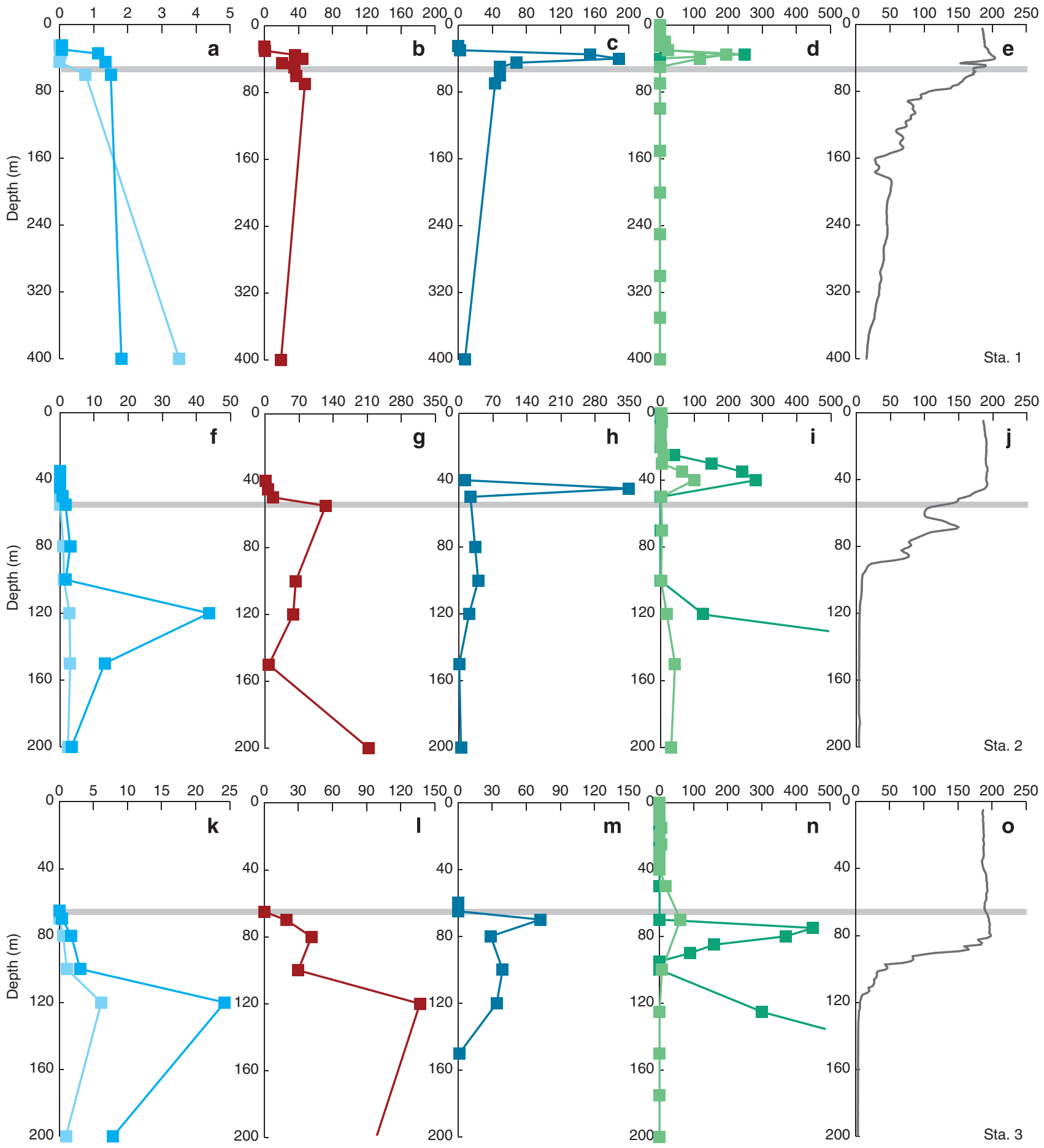

Figure 2 Depth profiles from (a-e) station 1, (f-j) station 2 and (k-o) station 3 in the ETNP and GOC. (a, f, k) QPCR data (10 ${ }^{3}$ 16S rRNA genes per $\mathrm{ml}$ ) and pyrosequencing data (expressed as $\%$ of total $16 \mathrm{~S}$ rRNA sequence for a given sample) for $\mathrm{Nitrospina}$ (b, $\mathbf{g}$, l) ${ }^{15} \mathrm{NO}_{2}^{-}$ oxidation rates (in nmoll $\left.{ }^{-1} \mathrm{~d}^{-1}\right) ;(\mathbf{c}, \mathbf{h}, \mathbf{m}){ }^{15} \mathrm{NH}_{4}^{+}$oxidation rates; (d, i, n) $\mathrm{NH}_{4}^{+}$and $\mathrm{NO}_{2}^{-}$concentrations (nmol $1^{-1}$ ); and (e, j, o) $\mathrm{DO}^{-}$ concentrations $\left(\mu \mathrm{mol} \mathrm{kg}{ }^{-1}\right)$. s.e. for QPCR fall within the width of the data points, and the gray line denotes the depth of the euphotic zone (that is, $1 \%$ of surface photosynthetically active radiation). All data are plotted to $200 \mathrm{~m}$ depth, with the exception of station 1 data, which are plotted to $400 \mathrm{~m}$ depth. Note that horizontal axes vary between $\mathbf{a}, \mathbf{f}$ and $\mathbf{k}$, and between $\mathbf{b}$, $\mathbf{g}$ and $\mathbf{l}$, but $\mathbf{c}, \mathbf{h}$ and $\mathbf{m}$ are identical to corresponding $\mathbf{b}, \mathbf{g}$ and $\mathbf{l}$ to allow comparison between ${ }^{15} \mathrm{NO}_{2}^{-}$and ${ }^{15} \mathrm{NH}_{4}^{+}$oxidation rates. 

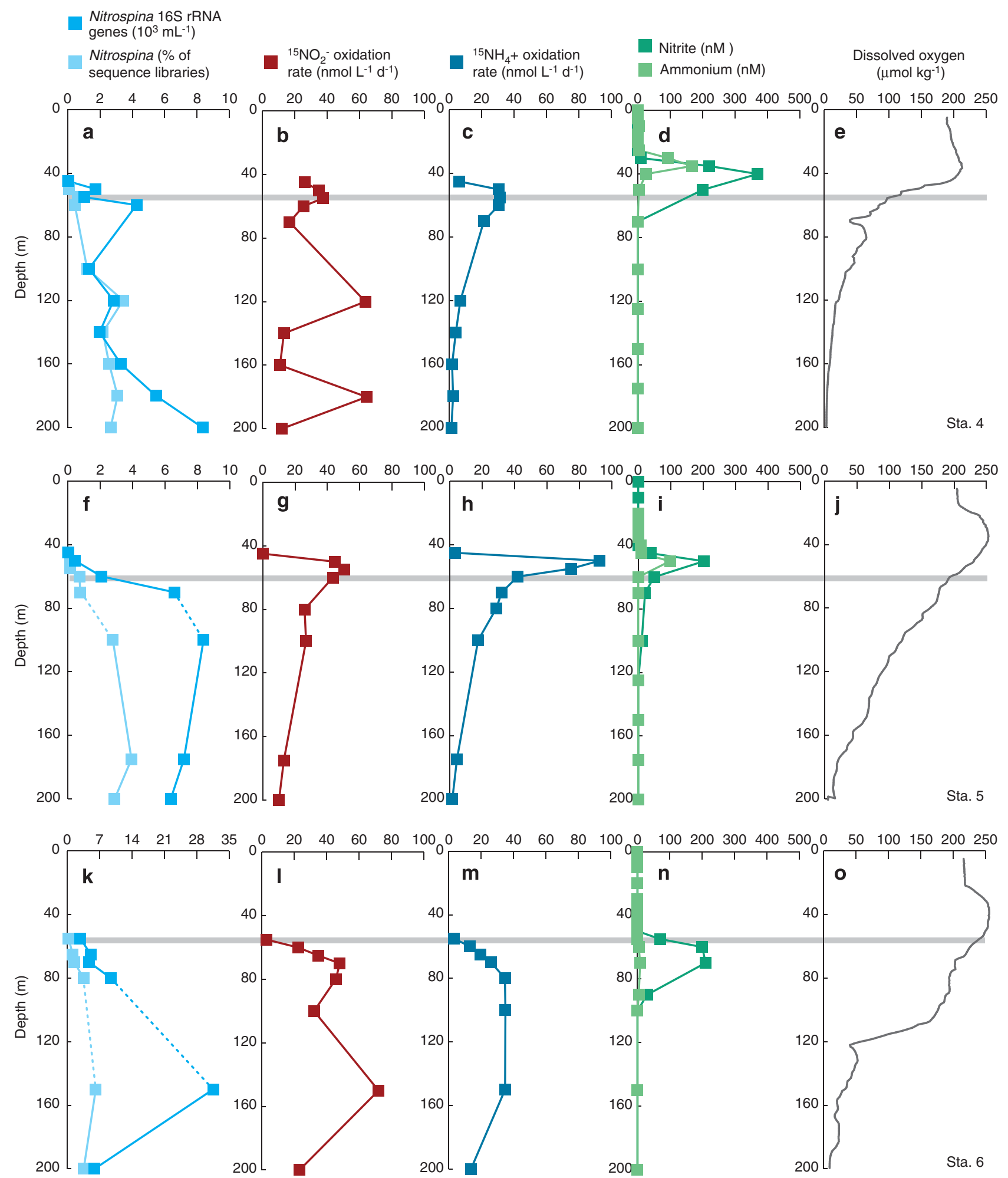

$1 \%$ Surface PAR

Figure 3 Depth profiles from (a-e) station 4, (f-j) station 5 and (k-o) station 6 in the ETNP and GOC. (a, f, k) QPCR data (10 16 S rRNA genes per $\mathrm{ml}$ ) and pyrosequencing data (expressed as \% of total $16 \mathrm{~S}$ rRNA sequence for a given sample) for Nitrospina; $(\mathbf{b}, \mathbf{g}, \mathbf{l})^{15} \mathrm{NO}_{2}^{-}$ oxidation rates (in nmoll $\left.{ }^{-1} \mathrm{~d}^{-1}\right) ;(\mathbf{c}, \mathbf{h}, \mathbf{m}){ }^{15} \mathrm{NH}_{4}^{+}$oxidation rates; $(\mathbf{d}, \mathbf{i}, \mathbf{n}) \mathrm{NH}_{4}^{+}$and $\mathrm{NO}_{2}^{-}\left(\mathrm{nmoll} \mathrm{l}^{-1}\right.$ ); and $(\mathbf{e}, \mathbf{j}, \mathbf{o})$ DO concentrations $\left(\mu \mathrm{mol} \mathrm{kg}{ }^{-1}\right)$. Standard errors for QPCR fall within the width of the data points, and dashed lines connecting data points denote presence of DNA samples with QPCR inhibition (which are subsequently excluded from statistical analyses). The gray line denotes the depth of the euphotic zone, and all data are plotted to $200 \mathrm{~m}$ depth. Note that horizontal axes vary between $\mathbf{a}, \mathbf{f}$ and $\mathbf{k}, \mathrm{but} \mathbf{b}, \mathbf{g}, \mathbf{l}$ and $\mathbf{c}, \mathbf{h}, \mathbf{m}$ are plotted on identical axes to allow comparison between ${ }^{15} \mathrm{NO}_{2}^{-}$and ${ }^{15} \mathrm{NH}_{4}^{+}$oxidation rates. 
a

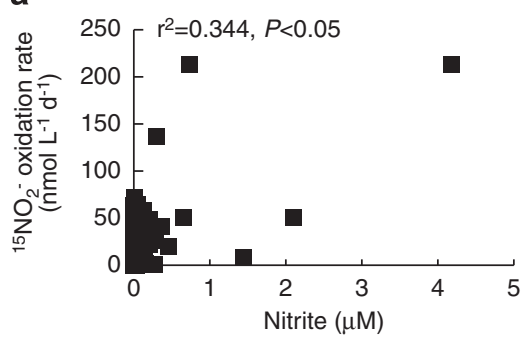

C

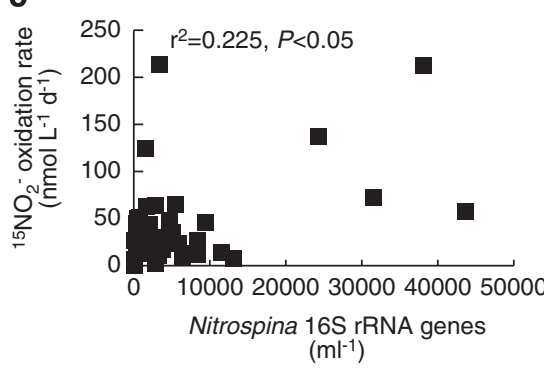

b
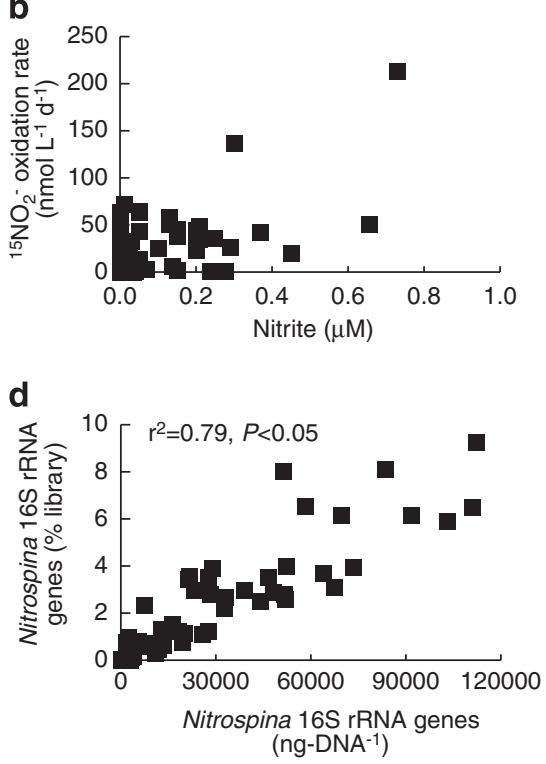

Figure 4 Correlations between ${ }^{15} \mathrm{NO}_{2}^{-}$oxidation rates and (a and $\left.\mathbf{b}\right) \mathrm{NO}_{2}^{-}$concentrations and (c) Nitrospina 16S rRNA gene abundance $\left(\mathrm{ml}^{-1}\right)$ based on QPCR. In $\mathbf{b}$, data points with $>1 \mu \mathrm{M} \mathrm{NO}_{2}^{-}$are not shown in order to show points near the axes. (d) Correlation between Nitrospina as a percentage of pyrosequencing libraries (vertical axis) and Nitrospina 16S rRNA gene abundance (ng-DNA ${ }^{-1}$ ) based on QPCR (horizontal axis). QPCR data are normalized per ng-DNA rather than per ml to reflect Nitrospina 16S rRNA genes as a proportion of community DNA.

Table $1 r^{2}$ values for the relationships between nitrite oxidation rates, ammonia oxidation rates, NOB abundance and dissolved nitrite

\begin{tabular}{lcll} 
Station & $\begin{array}{c}\text { Nitrite oxida- } \\
\text { tion vs nitrite }\end{array}$ & $\begin{array}{c}\text { Nitrite oxidation vs } \\
\text { ammonia oxidation }\end{array}$ & $\begin{array}{c}\text { Nitrite oxidation } \\
\text { vs Nitrospina }\end{array}$ \\
\hline 1 & 0.021 & $0.401^{*}$ & 0.126 \\
2 & $0.443^{*}$ & 0.038 (negative) & 0.135 \\
3 & 0.013 & 0.003 & $0.881^{*}$ \\
4 & 0.003 & 0.001 & 0.004 (negative) \\
5 & $0.443^{*}$ & $0.790^{*}$ & 0.085 (negative) \\
6 & 0.027 & $0.731^{*}$ & $0.647^{*}$ \\
Overall & $0.344^{*}$ & 0.000 & $0.225^{*}$ \\
\hline
\end{tabular}

${ }^{*} P<0.05$.

Most other studies have either not analyzed this relationship or have too few data points to adequately do so, but Ward (1987) proposed that substrate supply may limit $\mathrm{NO}_{2}^{-}$oxidation, and our results are consistent with this suggestion. Lipschultz et al. (1990) also reported strong correspondence between $\mathrm{NO}_{2}^{-}$concentrations and $\mathrm{NO}_{2}^{-}$ oxidation rates in the OMZ of the ETSP.

${ }^{15} \mathrm{NO}_{2}^{-}$oxidation and ${ }^{15} \mathrm{NH}_{4}^{+}$oxidation were correlated $\left(r^{2}=0.40-0.79, P<0.05\right)$ at stations 1,5 and 6 consistent with biogeochemical coupling between the two steps of nitrification (Figures 2 and 3). However, ${ }^{15} \mathrm{NH}_{4}^{+}$oxidation occurred up to 11 times more rapidly than ${ }^{15} \mathrm{NO}_{2}^{-}$oxidation in the upper water column at stations 1 and 5 , and 56 times more rapidly at station 2. At all of these stations, these rate differences fell within $5 \mathrm{~m}$ depth of the PNM where $\mathrm{NO}_{2}^{-}$accumulates to concentrations of hundreds nM. In the most extreme case, ${ }^{15} \mathrm{NH}_{4}^{+}$ oxidation rates were $342 \mathrm{nmoll}^{-1} \mathrm{~d}^{-1}$ greater than ${ }^{15} \mathrm{NO}_{2}^{-}$oxidation rates at $45 \mathrm{~m}$ at station 2 (Figures $2 \mathrm{~g}-\mathrm{i}$ ). At station $1,{ }^{15} \mathrm{NH}_{4}^{+}$oxidation was $119 \mathrm{nmoll}{ }^{-1} \mathrm{~d}^{-1}$ greater than ${ }^{15} \mathrm{NO}_{2}^{-}$oxidation, and the PNM was $249 \mathrm{~nm}$ at $35 \mathrm{~m}$ (Figures 2b-d); at station 5 , the rate mismatch was $48.1 \mathrm{nmoll}^{-1} \mathrm{~d}^{-1}$ at the 203 nM PNM (Figures 3g-i). At these depths and stations, decoupling between $\mathrm{NH}_{3}$ and $\mathrm{NO}_{2}^{-}$oxidation could potentially produce the PNM in $2-5$ days and possibly in $<1$ day at station 2 . This is consistent with previous estimates from the Atlantic by Clark et al. (2008); they calculated that $\mathrm{NH}_{3}$ oxidation could replace $>50 \%$ of the $\mathrm{NO}_{2}^{-}$pool within $24 \mathrm{~h}$ at most of the stations investigated. The data presented here also support our previous contention that $\mathrm{NH}_{3}$ oxidation contributes to generation of the PNM at stations 1 and 5 in the GOC and ETNP (Beman et al., 2012). With our coupled ${ }^{15} \mathrm{NH}_{4}^{+}$and ${ }^{15} \mathrm{NO}_{2}^{-}$oxidation data, we note that differential sensitivity to light does not appear to be a driving factor, because ${ }^{15} \mathrm{NO}_{2}^{-}$oxidation occurred in the euphotic zone and was correlated with ${ }^{15} \mathrm{NH}_{4}^{+}$oxidation in some cases. This is an important distinguishing factor from previous work, which has not measured ${ }^{15} \mathrm{NH}_{4}^{+}$and ${ }^{15} \mathrm{NO}_{2}^{-}$ oxidation at high resolution with depth (Ward, 1987, Lipschultz et al., 1990; Dore and Karl, 1996; Bianchi et al., 1999; Clark et al., 2008; Füssel et al., 2012), as we have here (5-10 m intervals in the upper water column). On the basis of our data, the fact that $\mathrm{NH}_{3}$ oxidation rates exceed $\mathrm{NO}_{2}^{-}$oxidation rates appears to be the key in generating the PNM within the upper water column. 
OMZ $\mathrm{NO}_{2}^{-}$oxidation

At stations 2,3 and $4,{ }^{15} \mathrm{NO}_{2}^{-}$was oxidized most rapidly $\left(63.7-213 \mathrm{nmoll}^{-1} \mathrm{~d}^{-1}\right)$ at depths $>120 \mathrm{~m}$, where oxygen concentrations were low (1.8-8.4 $\left.\mu \mathrm{mol} \mathrm{kg}{ }^{-1}\right)$. Here, ${ }^{15} \mathrm{NO}_{2}^{-}$oxidation rates were much greater than ${ }^{15} \mathrm{NH}_{4}^{+}$oxidation rates; ${ }^{15} \mathrm{NH}_{4}^{+}$oxidation was detected in the OMZ, but was typically $<5 \mathrm{nmoll}^{-1} \mathrm{~d}^{-1}$ and declined with decreasing DO, such that ${ }^{15} \mathrm{NH}_{4}^{+}$oxidation rates were positively correlated with DO concentrations at stations $1-5\left(r^{2}=0.51-0.98\right.$; Beman et al., 2012). In contrast, ${ }^{15} \mathrm{NO}_{2}^{-}$oxidation was uncorrelated with $\mathrm{DO}$, and ${ }^{15} \mathrm{NO}_{2}^{-}$oxidation was up to 50 times more rapid than ${ }^{15} \mathrm{NH}_{4}^{+}$oxidation. This represents decoupling between $\mathrm{NH}_{3}$ and $\mathrm{NO}_{2}^{-}$oxidation in the OMZ, and is a probable result of the high concentrations of available $\mathrm{NO}_{2}^{-}$. At stations 2 and $3, \mathrm{NO}_{2}^{-}$accumulates to concentrations of up to $4.2 \mu \mathrm{M}$ at $150-200 \mathrm{~m}$; our highest measured rates $\left(213 \mathrm{nmol} \mathrm{l}^{-1} \mathrm{~d}^{-1}\right)$ were measured at 200 and $250 \mathrm{~m}$ in the OMZ at station $2 . \mathrm{NO}_{2}^{-}$concentrations were not as high in the OMZ at station 4, but they were greater than that at stations 1,5 and 6 (for example, $114 \mathrm{nM}$ at $400 \mathrm{~m}$ at station 4 ). These accumulations of $\mathrm{NO}_{2}^{-}$evidently allow $\mathrm{NOB}$ to oxidize $\mathrm{NO}_{2}^{-}$within the OMZ in spite of low oxygen concentrations, and are consistent with previous work by Lipschulz et al. (1990) and a more recent work by Füssel et al. (2012) in other OMZs. Lipschultz et al. (1990) found rates of up to $600 \mathrm{nmoll}^{-1} \mathrm{~d}^{-1}$ at $\sim 1 \mu \mathrm{M}$ DO in ETSP, and Füssel et al. (2012) reported rates of $372 \mathrm{nmoll}^{-1}$ $\mathrm{d}^{-1}$ at $<1 \mu \mathrm{M}$ DO off Namibia. $\mathrm{NO}_{2}^{-}$oxidation appears to be an important form of microbial metabolism in OMZs (for example, Wright et al., 2012, Ulloa et al., 2012), and the high rates we observed within the oceans' largest OMZ lend further support to this hypothesis.

In previous studies, $\mathrm{NO}_{2}^{-}$oxidation persisted under low DO because these conditions permit $\mathrm{NO}_{3}^{-}$reduction (Lipschulz et al., 1990, Füssel et al., 2012), which produces $\mathrm{NO}_{2}^{-}$that may be oxidized back to $\mathrm{NO}_{3}^{-}$, or used by anammox or denitrification as an oxidant. Alongside measurements of $\mathrm{NO}_{2}^{-}$oxidation, both Lipschultz and colleagues (1990) and Füssel et al. (2012) measured $\mathrm{NO}_{3}^{-}$reduction in the ETSP and Namibian OMZs, finding generally good correspondence between $\mathrm{NO}_{3}^{-}$reduction and $\mathrm{NO}_{2}^{-}$oxidation in magnitude and depth distribution. Lam et al. (2009) also found that $\mathrm{NO}_{3}^{-}$reduction rates were high in the Peruvian $\mathrm{OMZ}$, and detected $\mathrm{NO}_{3}^{-}$reductase gene expression (narG and napA) where $\mathrm{NO}_{3}^{-}$reduction was also measured. We screened OMZ RNA samples where dissolved $\mathrm{NO}_{2}^{-}$exceeded $500 \mathrm{~nm}$ for narG and napA expression; this $\mathrm{NO}_{2}^{-}$threshold defines anoxic waters based on recent measurements in the ETSP (Thamdrup et al., 2012, Ulloa et al., 2012), and includes samples from $150-300 \mathrm{~m}$ at station 2 and 200-300 $\mathrm{m}$ at station 3. We found expression of narG, napA or both, in all of these samples, indicating that $\mathrm{NO}_{3}^{-}$reduction is a possible source of $\mathrm{NO}_{2}^{-}$that may then be oxidized back to $\mathrm{NO}_{3}^{-}$.

Taking a step back, our results indicate that coupling between $\mathrm{NH}_{3}$ and $\mathrm{NO}_{2}^{-}$oxidation is uncommon in the GOC and ETNP. Station 6 was the only station where ${ }^{15} \mathrm{NH}_{4}^{+}$and ${ }^{15} \mathrm{NO}_{2}^{-}$oxidation rates were correlated and similar in magnitude. Instead, quantitative differences in ${ }^{15} \mathrm{NH}_{4}^{+}$and ${ }^{15} \mathrm{NO}_{2}^{-}$oxidation rates in the upper water column, and high ${ }^{15} \mathrm{NO}_{2}^{-}$oxidation rates measured within the $\mathrm{OMZ}$, indicate that $\mathrm{NH}_{3}$ and $\mathrm{NO}_{2}^{-}$oxidation are not tightly connected, and shift in and out of equilibrium in the ETNP. This does not mean that these processes are decoupled over long time scales: they cannot be, as $\mathrm{NO}_{2}^{-}$would accumulate where $\mathrm{NH}_{3}$ oxidation or $\mathrm{NO}_{3}^{-}$reduction exceeds $\mathrm{NO}_{2}^{-}$ oxidation, or be rapidly consumed where $\mathrm{NO}_{2}^{-}$ oxidation exceeds $\mathrm{NO}_{2}^{-}$supply.

\section{NOB communities}

Of the different $\mathrm{NOB}$ that may oxidize $\mathrm{NO}_{2}^{-}$, Nitrospina bacteria are hypothesized to have a key role in the oceanic $\mathrm{NO}_{2}^{-}$oxidation (Mincer et al., 2007) and comprised up to $9.25 \% 16 \mathrm{~S}$ rRNA gene sequences recovered in our sequence libraries (250 $\mathrm{m}$ at station 2). This indicates that Nitrospina constitute a substantial proportion of the bacterial community in the ETNP, and raises the possibility that Nitrospina may be abundant elsewhere in the ocean. Nitrospina typically increased in relative proportions up to 100-200 $\mathrm{m}$ depth (light blue lines in Figures 2 and $3 \mathrm{a}, \mathrm{f}, \mathrm{k}$ ), and their maximum proportions ranged from 3.09 to $6.52 \%$ across the other stations. Throughout our extensive pyrosequencing data set, we found little evidence that other NOB are present in GOC and ETNP. Out of 420240 sequences, Nitrococcus and Nitrobacter were never detected, and a single Nitrospira 16S rRNA gene sequence was detected at $100 \mathrm{~m}$ at station 4 . In the Namibian OMZ, Füssel et al. (2012) found that Nitrospina (up to $5.4 \%$ of microbial cells) and Nitrococcus (up to $4.9 \%$ of microbial cells) were both abundant, and the sum of these groups (0.3-9\%) was similar to the relative abundance of Nitrospina that we observed (although their direct counts include Archaea, whereas our data are based on relative proportions within bacterial sequence libraries). We also found strong positive correlation between the proportion of Nitrospina in our pyrosequencing data set and Nitrospina 16S rRNA genes based on QPCR (normalized per ng-DNA, to reflect gene abundance relative to total extracted microbial DNA; $r^{2}=0.79, P<0.05$; Figure $4 d$ ). This correlation with QPCR data indicates that the pyrosequencing data reflect the proportions of different groups within the water column, and that other NOB are therefore substantially less abundant than the Nitrospina in GOC and ETNP.

We examined different Nitrospina ecotypes present in the GOC and ETNP by clustering all 
classified Nitrospina sequences into OTUs based on 97\% sequence identity. We found a few dominant OTUs, with $66.2 \%$ of Nitrospina sequences affiliated with just three of them: $24.6 \%$ were affiliated with the most abundant OTU, 21.7\% with the next most abundant and $19.9 \%$ with the third most abundant OTU (Table 2). Nitrospina represented $2.14 \%$ of all recovered $16 \mathrm{~S}$ rRNA sequences, so each of these top three Nitrospina OTUs constitute $0.4-0.5 \%$ of all $16 \mathrm{~S}$ rRNA gene sequences. The remaining 473 Nitrospina OTUs each contained $3.6 \%$ or fewer of the Nitrospina sequences. With a few abundant OTUs, and many uncommon OTUs, Nitrospina OTU rank abundance was power law-scaled $\left(r^{2}=0.923 ;\right.$ Nitrospina sequences in OTU $=1003.1^{*} \mathrm{OTU}$ rank $\left.^{-1.209}\right)$. This is a general property of many ecological communities (Fuhrman, 2009) that Nitrospina also follow in the GOC and ETNP. Meta-analysis by Wright et al. (2012) showed that other common OMZ bacteria-such as SUP05/ARCTIC96BD-19 and SAR324-are likewise divided into multiple ecotypes, including some that are dominant and nearly ubiquitous, and many others that are less common. Although Nitrospina are frequently detected in OMZs and may have an important role in $\mathrm{N}$ cycling within them, Wright et al. (2012) did not analyze Nitrospina in a similar way; our results indicate that Nitrospina communities share similar properties to other typical OMZ bacteria.
GOC and ETNP Nitrospina OTUs also exhibited 98-99\% similarity to database $16 \mathrm{~S}$ rRNA sequences recovered from other regions of the ocean (Table 2). This includes surface waters (25-49 m depth) of the Arabian Sea (99\% identical to OTU 10; Fuchs et al., 2005), suboxic to anoxic waters at $119-130 \mathrm{~m}$ depth in the Namibian upwelling system (OTU 7; Woebken et al., 2007), suboxic waters at $890 \mathrm{~m}$ depth in the San Pedro Basin (OTU 1; Brown et al., 2005; Beman et al., 2010) and $100 \mathrm{~m}$ in the Saanich Inlet, which is typically anoxic below this depth (OTUs 4 and 9; Walsh et al., 2009). OTUs 5, 8 and 11 were similar to sequences recovered from 200 to $800 \mathrm{~m}$ depth in the Gulf of Mexico or at Station Aloha in the North Pacific subtropical gyre (Rich et al., 2011; Swan et al., 2011; Redmond and Valentine, 2012), whereas OTUs 2, 3 and 6 were $99 \%$ identical to sequences previously recovered in the GOC (Dick and Tebo, 2010) or ETNP (Ma et al., 2009). Given the high sequence similarity to these database sequences and the diversity of oceanic regions represented by them, all of these Nitrospina OTUs appear widely distributed and may be important $\mathrm{NO}_{2}^{-}$oxidizers elsewhere in the ocean. In the ETNP, our data provide an in-depth view of Nitrospina in world's largest OMZ, and indicate that thousands of Nitrospina sequences and hundreds of Nitrospina OTUs are spread across a range of DO concentrations.

Table 2 Dominant Nitrospina operational taxonomic units (OTUs), percentage of sequences, distribution in the water column and similarity to database sequences

\begin{tabular}{|c|c|c|c|c|c|c|c|c|}
\hline \multirow[t]{2}{*}{ OTU } & \multirow{2}{*}{$\begin{array}{c}\% \text { of } \\
\text { Nitrospina } \\
\text { sequences }\end{array}$} & \multicolumn{2}{|c|}{ Depth range } & \multirow{2}{*}{$\begin{array}{l}\text { Nitrospina GenBank } \\
\text { accession number }\end{array}$} & \multirow{2}{*}{$\begin{array}{l}\text { Nearest GenBank sequence } \\
\text { (accession number) }\end{array}$} & \multirow{2}{*}{$\begin{array}{l}\text { Depth } \\
\text { (m) }\end{array}$} & \multirow{2}{*}{$\begin{array}{c}\text { Shared } \\
\text { identity } \\
(\%)\end{array}$} & \multirow[t]{2}{*}{ Reference } \\
\hline & & $\underset{(\mathrm{m})}{\operatorname{Minimum}}$ & $\underset{(\mathrm{m})}{\operatorname{Maximum}}$ & & & & & \\
\hline 1 & 24.6 & 60 & 800 & KC775278 & $\begin{array}{l}\text { San Pedro Basin, California } \\
\text { (DQ009478) }\end{array}$ & 890 & 99 & $\begin{array}{l}\text { Brown et al. } \\
(2005)\end{array}$ \\
\hline 2 & 21.7 & 55 & 800 & KC775277 & $\begin{array}{l}\text { Carmen Basin, Gulf of } \\
\text { California (FJ981406) }\end{array}$ & 2000 & 99 & $\begin{array}{l}\text { Dick and Tebo } \\
\text { (2010) }\end{array}$ \\
\hline 3 & 19.9 & 100 & 800 & KC775276 & $\begin{array}{l}\text { Eastern Tropical North Pacific } \\
\text { (AY726827) }\end{array}$ & 100 & 99 & Ma et al. (2009) \\
\hline 4 & 3.6 & 50 & 550 & KC775275 & $\begin{array}{l}\text { Saanich Inlet, Canada } \\
\text { (GQ349069) }\end{array}$ & 100 & 99 & $\begin{array}{l}\text { Walsh et al. } \\
\text { (2009) }\end{array}$ \\
\hline 5 & 2.7 & 70 & 800 & KC775274 & $\begin{array}{l}\text { Hawaii Ocean Time-series } \\
\text { (HQ675664) }\end{array}$ & 770 & 99 & $\begin{array}{l}\text { Swan et al. } \\
\text { (2011) }\end{array}$ \\
\hline 6 & 2.0 & 375 & 800 & KC775273 & $\begin{array}{l}\text { Guaymas Basin, Gulf of } \\
\text { California (FJ981193) }\end{array}$ & 1503 & 99 & $\begin{array}{l}\text { Dick and Tebo } \\
\text { (2010) }\end{array}$ \\
\hline 7 & 1.5 & 50 & 550 & KC775272 & $\begin{array}{l}\text { Namibian upwelling system, } \\
\text { clone N67e_42 (EF646085) }\end{array}$ & 119-130 & 99 & $\begin{array}{l}\text { Woebken et al. } \\
(2007)\end{array}$ \\
\hline 8 & 1.4 & 55 & 750 & KC775271 & $\begin{array}{l}\text { Gulf of Mexico, non-plume } \\
\text { sample W65-11 (JN018903) }\end{array}$ & 800 & 99 & $\begin{array}{l}\text { Redmond and } \\
\text { Valentine (2012) }\end{array}$ \\
\hline 9 & 1.1 & 60 & 600 & KC775270 & $\begin{array}{l}\text { Saanich Inlet, Canada } \\
\text { (GQ349960) }\end{array}$ & 100 & 99 & $\begin{array}{l}\text { Walsh et al. } \\
(2009)\end{array}$ \\
\hline 10 & 1.1 & 50 & 550 & KC775269 & $\begin{array}{l}\text { Arabian Sea, station B } \\
\text { high-nucleic acid sample } \\
\text { (AY907818) }\end{array}$ & $25-49$ & 98 & $\begin{array}{l}\text { Fuchs et al. } \\
\text { (2005) }\end{array}$ \\
\hline 11 & 1.0 & 50 & 500 & KC775268 & $\begin{array}{l}\text { Hawaii Ocean Time-series } \\
\text { (GU474877) }\end{array}$ & 200 & 98 & $\begin{array}{l}\text { Rich et al. } \\
\text { (2011) }\end{array}$ \\
\hline
\end{tabular}


Nitrospina and $\mathrm{NO}_{2}^{-}$oxidation

For the entire data set, QPCR-determined Nitrospina 16S rRNA gene abundances $\left(\mathrm{ml}^{-1}\right)$ were significantly correlated with ${ }^{15} \mathrm{NO}_{2}^{-}$oxidation rates $\left(r^{2}=0.225 P<0.05\right.$; Figure $\left.4 \mathrm{c}\right)$. Like other variables we examined, the strength of this relationship varied from station to station, with strongest correspondence at stations 3 and 6 (Table 1). We computed the distribution of different Nitrospina OTUs throughout the water column based on these QPCR data and the proportion of Nitrospina sequences that were affiliated with the different OTUs (Figure 5; see Materials and Methods and Carlson et al., 2009). Although these PCR-based approaches introduce uncertainties that preclude further quantitative analysis, there are few practical alternatives, as OTU-specific QPCR primers likely have their own biases, as would microarrays with OTU-specific probes; we use these data to demonstrate the vertical distribution of the Nitrospina OTUs.

Across this data set, no single OTU was found at all depths where $\mathrm{NO}_{2}^{-}$was oxidized, indicating that multiple Nitrospina OTUs must govern the process across the GOC and ETNP. The three dominant Nitrospina OTUs showed slightly different depth distributions, with the third most abundant OTU confined to a smaller depth range than the other two (Table 2), but displaying greater constancy with depth (Figure 5b). All three of these OTUs were uncommon in the upper water column, where high rates of ${ }^{15} \mathrm{NO}_{2}^{-}$oxidation nevertheless occur; a good example of this is the peak in ${ }^{15} \mathrm{NO}_{2}^{-}$oxidation rates found at $55 \mathrm{~m}$ at station 2, where none of the dominant OTUs were present. OTUs 7, 10 and 11 were the only Nitrospina detected at this depth, as well as in other samples collected at $<100 \mathrm{~m}$ depth (Figure 5c). Their presence where other Nitrospina are absent suggests that they contribute to $\mathrm{NO}_{2}^{-}$ oxidation in the upper water column.
Together with the fact that only a single $16 \mathrm{~S}$ rRNA gene from other NOB was detected in our pyrosequencing data set, and that Nitrospina abundance based on QPCR was correlated with ${ }^{15} \mathrm{NO}_{2}^{-}$ oxidation rates, these findings indicate that (1) Nitrospina oxidize $\mathrm{NO}_{2}^{-}$in the ETNP and GOC and (2) a mixture of Nitrospina OTUs contribute at different depths. Untangling the relative contributions of these OTUs may be possible through quantifying OTU-specific $\mathrm{NO}_{2}^{-}$oxidoreductase (nxr) gene expression, but requires (meta)genomic/ transcriptomic data for the different Nitrospina OTUs. In the absence of such published data, our approach identifies Nitrospina that are candidates for additional study in other OMZs and other regions of the sea. More specifically, the more abundant OTUs identified here are widespread in the ETNP OMZ, whereas OTUs 7, 10 and 11 are less abundant overall, but appear important in the well-oxygenated upper water column.

\section{Conclusions}

We report the first ${ }^{15} \mathrm{NO}_{2}^{-}$oxidation measurements from the ETNP, and show that the two steps of nitrification were rarely connected. $\mathrm{NO}_{2}^{-}$oxidation may be coupled to anaerobic processes that produce $\mathrm{NO}_{2}^{-}$in the OMZ. $\mathrm{NO}_{2}^{-}$concentrations correlated with ${ }^{15} \mathrm{NO}_{2}^{-}$oxidation rates and the highest rates were observed in the OMZ, where $\mathrm{NO}_{2}^{-}$concentrations were elevated. High Nitrospina abundances (based on pyrosequencing), the lack of other detectable NOB and significant correlations with ${ }^{15} \mathrm{NO}_{2}^{-}$ oxidation rates (based on QPCR) all indicate that Nitrospina are dominant NOB in the GOC and ETNP. For the first time, we show that Nitrospina constitute a large percentage of the bacterial community (up to $9.25 \%$ ) and are grouped into

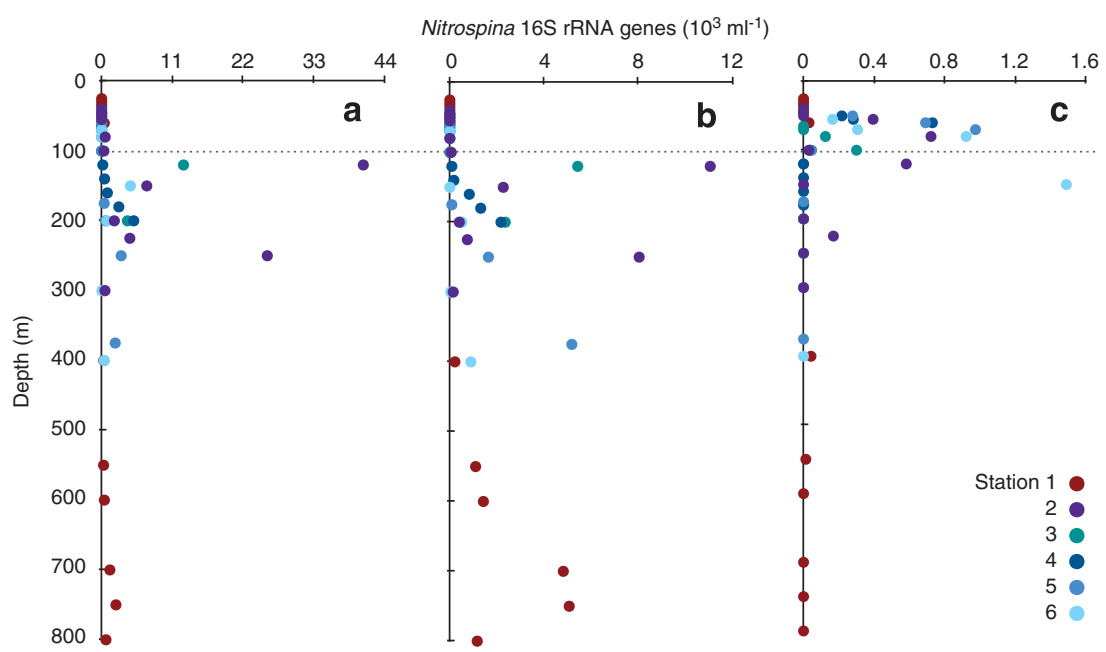

Figure 5 Distribution of Nitrospina ecotypes with depth across stations: (a) the most abundant OTU, (b) the third most common OTU and (c) the 7 th most abundant OTU. Colors indicate different stations and data are expressed as $10^{3} 16 \mathrm{~S}$ rRNA genes per ml. 
multiple OTUs that are distributed heterogenously with depth. Many of these OTUs are highly similar to sequences recovered from other areas of the ocean and may represent biogeochemically important populations of Nitrospina. Given this sequence diversity and ecological diversity within the Nitrospina, we suggest that the genomic and metabolic diversity of these putative ecotypes should be explored, such that their relative contributions to $\mathrm{NO}_{2}^{-}$oxidation at different depths and in different oceanic regions may be determined. In the ETNP and other OMZs, $\mathrm{NO}_{2}^{-}$cycling is central and Nitrospina are widespread, abundant and diverse. Our findings support the idea that Nitrospina are key contributors to oceanic $\mathrm{NO}_{2}^{-}$ oxidization, and provide new insight into their ecology and rates of $\mathrm{N}$ cycling, within the oceans' largest, and expanding OMZ.

\section{Conflict of Interest}

The authors declare no conflicts of interest.

\section{Acknowledgements}

We thank Fred Prahl (chief scientist), Jackie Mueller, Natalie Wallsgrove, Jason Smith, Julie Fliegler and the officers and crew of the R/V New Horizon for assistance in the field. We also thank Rachel Foster for supplying critical DNA samples, Susan Alford, Molly Carolan and Natalie Wallsgrove for assistance with laboratory analyses. This work was supported by National Science Foundation Oceanography Award 10-34943 to JMB and BNP, and this is School of Ocean and Earth Science and Technology Contribution number 8809.

\section{References}

Beman JM, Popp BN, Alford SE. (2012). Quantification of ammonia oxidation rates and ammonia-oxidizing archaea and bacteria at high resolution in the Gulf of California and eastern tropical North Pacific Ocean. Limnol Oceanog 57: 711-726.

Beman JM, Popp BN, Francis CA. (2008). Molecular and biogeochemical evidence for ammonia oxidation by marine Crenarchaeota in the Gulf of California. ISME J 2: 429-441.

Beman JM, Sachdeva R, Fuhrman JA. (2010). Population ecology of nitrifying Archaea and bacteria in the Southern California Bight. Environ Microbiol 12: 1282-1292.

Bianchi M, Fosset C, Conan P. (1999). Nitrification rates in the NW Mediterranean Sea. Aquat Microb Ecol 17: 267-278.

Brown MV, Philip GK, Bunge JA, Smith MC, Bissett A, Lauro FM et al. (2009). Microbial community structure in the North Pacific ocean. ISME J 3: 1374-1386.

Brown MV, Schwalbach M, Hewson I, Fuhrman JA. (2005). Coupling 16S-ITS rDNA clone libraries and automated ribosomal intergenic spacer analysis to show marine microbial diversity: development and application to a time series. Environ Microbiol 7: 1466-1479.

Carlson CA, Morris R, Parsons R, Treusch AH, Giovannoni SJ, Vergin K. (2009). Seasonal dynamics of SAR11 populations in the euphotic and mesopelagic zones of the northwestern Sargasso Sea. ISME J 3: 283-295.

Casciotti KL, McIlvin MR. (2007). Isotopic analyses of nitrate and nitrite from reference mixtures and application to Eastern Tropical North Pacific waters. Mar Chem 107: 184-201.

Church MJ, Short CM, Jenkins BD, Karl DM, Zehr JP. (2005). Temporal patterns of nitrogenase gene (nifH) expression in the oligotrophic North Pacific Ocean. Appl Environ Microbiol 71: 5362-5370.

Clark DR, Rees AP, Joint I. (2008). Ammonium regeneration and nitrification rates in the oligotrophic Atlantic Ocean: implications for new production estimates. Limnol Oceanog 53: 52-62.

Costa E, Pérez J, Kreft J. (2006). Why is metabolic labour divided in nitrification? Trends Microbiol 14: 213-219.

DeSantis TZ, Hugenholtz P, Larsen N, Rojas M, Brodie EL, Keller K et al. (2006). Greengenes, a chimera-checked $16 \mathrm{~S}$ rRNA gene database and workbench compatible with ARB. Appl Environ Microbiol 72: 5069-5072.

Deutsch C, Brix H, Ito T, Frenzel H, Thompson L. (2011). Climate-forced variability of ocean hypoxia. Science 333: 336-339.

DeVries T, Deutsch C, Primeau F, Chang B, Devol A. (2012). Global rates of water-column denitrification derived from nitrogen gas measurements. Nature Geosci 5: 547-550.

Dick GJ, Tebo BM. (2010). Microbial diversity and biogeochemistry of the Guaymas Basin deep-sea hydrothermal plume. Environ Microbiol 12: 1334-1347.

Dore JE, Karl DM. (1996). Nitrification in the euphotic zone as a source of nitrite, nitrate and nitrous oxide at station ALOHA. Limnol Oceanogr 41: 1619-1628.

Dore JE, Popp BN, Karl DM, Sansone FJ. (1998). A large source of atmospheric nitrous oxide from subtropical North Pacific surface waters. Nature 396: 63-66.

Engelbrektson A, Kunin V, Wrighton KC, Zvenigorodsky N, Chen F, Ochman $\mathrm{H}$ et al. (2010). Experimental factors affecting PCR-based estimates of microbial species richness and evenness. ISME J 4: 642-647.

Francis CA, Beman JM, Kuypers MMM. (2007). New processes and players in the nitrogen cycle: the microbial ecology of anaerobic and archaeal ammonia oxidation. ISME J 1: 19-27.

Fuchs BM, Woebken D, Zubkov MV, Burkill P, Amann R. (2005). Molecular identification of picoplankton populationsin contrasting waters of the Arabian Sea. Aquat Microb Ecol 39: 145-157.

Fuhrman JA. (2009). Microbial community structure and its functional implications. Nature 459: 193-199.

Füssel J, Lam P, Lavik G, Jensen MM, Holtappels M, Gunter $M$ et al. (2012). Nitrite oxidation in the Namibian oxygen minimum zone. ISME J 6: 12001209.

Galand PE, Casamayor EO, Kirchman DL, Lovejoy C. (2009). Ecology of the rare microbial biosphere of the Arctic Ocean. Proc Natl Acad Sci USA 106: 22427-22432.

Gilly WF, Beman JM, Litvin SY, Robison BH. (2013). Oceanographic and biological effects of shoaling of 
the oxygen minimum zone. Annu Rev Marine Sci 5: 393-420.

Graham DW, Knapp CW, Van Vleck ES, Bloor K, Lane TB, Graham CE. (2007). Experimental demonstration of chaotic instability in biological nitrification. ISME J 1: 385-393.

Granger J, Sigman DM. (2009). Removal of nitrite with sulfamic acid for nitrate $\mathrm{N}$ and $\mathrm{O}$ isotope analysis with the denitrifier method. Rapid Commun Mass Spectrom 23: 3753-3762.

Hamady M, Walker JJ, Harris JK, Gold NJ, Knight R. (2008). Error-correcting barcoded primers for pyrosequencing hundreds of samples in multiplex. Nat Meth 5: 235-237.

Holmes RM, Aminot A, Kérouel R, Hooker BA, Peterson BJ. (1999). A simple and precise method for measuring ammonium in marine and freshwater ecosystems. Can J FIsh Aquat Sci 56: 1801-1808.

Huse S, Huber J, Morrison H, Sogin M, Welch D. (2007). Accuracy and quality of massively parallel DNA pyrosequencing. Genome Biol 8: R143.

Karner MB, DeLong EF, Karl DM. (2001). Archaeal dominance in the mesopelagic zone of the Pacific Ocean. Nature 409: 507-510.

Keeling RF, Körtzinger A, Gruber N. (2010). Ocean deoxygenation in a warming world. Ann Rev Mar Sci 2: 199-229.

Lam P, Jensen MM, Lavik G, McGinnis DF, Muller B, Schubert CJ et al. (2007). Linking crenarchaeal and bacterial nitrification to anammox in the Black Sea. Proc Natl Acad Sci USA 104: 7104-7109.

Lam P, Kuypers MMM. (2011). Microbial nitrogen cycling processes in oxygen minimum Zones. Annu Rev Marine Sci 3: 317-345.

Lam P, Lavik G, Jensen MM, van dV, Schmid M, Woebken D et al. (2009). Revising the nitrogen cycle in the Peruvian oxygen minimum zone. Proc Natl Acad Sci USA 106: 4752-4757.

Lipschultz F, Wofsy SC, Ward BB, Codispoti LA, Friederich GE, Elkins JW. (1990). Bacterial transformations of inorganic nitrogen in the oxygen-deficient waters of the Eastern Tropical South Pacific Ocean. Deep Sea Res A 37: 1513-1541.

Lomas MW, Lipschultz F. (2006). Forming the primary nitrite maximum: nitrifiers or phytoplankton? Limnol Oceanog 51: 2453-2467.

Ma Y, Zeng Y, Jiao N, Shi Y, Hong N. (2009). Vertical distribution and phylogenetic composition of bacteria in the Eastern Tropical North Pacific Ocean. Microbiol Res 164: 624-633.

Mills MM, Ridame C, Davey M, La Roche J, Gelder RJ. (2004). Iron and phosphorus co-limit nitrogen fixation in the eastern tropical North Atlantic. Nature 429: 292-294.

Mincer TJ, Church MJ, Taylor LT, Preston CM, Karl DM, DeLong EF. (2007). Quantitative distribution of presumptive archaeal and bacterial nitrifiers in Monterey Bay and the North Pacific Subtropical Gyre. Environ Microbiol 9: 1162-1175.

Olson RJ. (1981). ${ }^{15} \mathrm{~N}$ tracer studies of the primary nitrite maximum. J Mar Res 39: 203-226.

Paulmier A, Ruiz-Pino D. (2009). Oxygen minimum zones (OMZs) in the modern ocean. Prog Oceanogr 80: 113-128.

Popp BN, Sansone FJ, Rust TM, Merritt DA. (1995). Determination of concentration and carbon isotopic composition of dissolved methane in sediments and nearshore waters. Anal Chem 67: 405-411.
Pruesse E, Quast C, Knittel K, Fuchs BM, Ludwig W, Peplies J et al. (2007). SILVA: a comprehensive online resource for quality checked and aligned ribosomal RNA sequence data compatible with ARB. Nucleic Acids Res 35: 7188-7196.

Redmond MC, Valentine DL. (2012). Natural gas and temperature structured a microbial community response to the Deepwater Horizon oil spill. Proc Natl Acad Sci USA 109: 20292-20297.

Rich VI, Pham VD, Eppley J, Shi Y, DeLong EF. (2011). Time-series analyses of Monterey Bay coastal microbial picoplankton using a 'genome proxy' microarray. Environ Microbiol 13: 116-134.

Santoro AE, Casciotti KL, Francis CA. (2010). Activity, abundance and diversity of nitrifying archaea and bacteria in the central California Current. Environ Microbiol 12: 1989-2006.

Schloss PD, Westcott SL, Ryabin T, Hall JR, Hartmann M, Hollister EB et al. (2009). Introducing mothur: opensource, platform-independent, community-supported software for describing and comparing microbial communities. Appl Environ Microbiol 75: 7537-7541.

Sigman DM, Casciotti KL, Andreani M, Barford C, Galanter M, Böhlke JK. (2001). A bacterial method for the nitrogen isotopic analysis of nitrate in seawater and freshwater. Anal Chem 73: 4145-4153.

Stramma L, Johnson GC, Sprintall J, Mohrholz V. (2008). Expanding oxygen-minimum zones in the tropical oceans. Science 320: 655-658.

Strickland JH, Parsons TR. (1972). A Practical Handbook of Seawater Analysis. Fisheries Research Board of Canada: Ottawa: Ontario, Canada.

Sutka RL, Ostrom NE, Ostrom PH, Phanikumar MS. (2004). Stable nitrogen isotope dynamics of dissolved nitrate in a transect from the North Pacific subtropical gyre to the eastern tropical North Pacific. Geochim Cosmochim Ac 68: 517-527.

Swan BK, Martinez-Garcia M, Preston CM, Sczyrba A, Woyke T, Lamy D et al. (2011). Potential for chemolithoautotrophy among ubiquitous bacteria lineages in the dark ocean. Science 333: 1296-1300.

Thamdrup B, Dalsgaard T, Revsbech NP. (2012). Widespread functional anoxia in the oxygen minimum zone of the Eastern South Pacific. Deep Sea Res I: Oceanog Res Papers 65: 36-45.

Ulloa O, Canfield DE, DeLong EF, Letelier RM, Stewart FJ. (2012). Microbial oceanography of anoxic oxygen minimum zones. Proc Natl Acad Sci USA 109: 15996-16003.

Walsh DA, Zaikova E, Howes CG, Song YC, Wright JJ, Tringe SG et al. (2009). Metagenome of a versatile chemolithoautotroph from expanding oceanic dead zones. Science 326: 578-582.

Ward BB. (1987). Nitrogen transformations in the Southern California Bight. Deep Sea Res A 34: 785-805.

Ward BB, Devol AH, Rich JJ, Chang BX, Bulow SE, Naik H et al. (2009). Denitrification as the dominant nitrogen loss process in the Arabian Sea. Nature 461: 78-81.

Ward BB, Glover HE, Lipschultz F. (1989a). Chemoautotrophic activity and nitrification in the oxygen minimum zone off Peru. Deep Sea Res A 36: 1031-1051.

Ward BB, Kilpatrick KA, Renger EH, Eppley RW. (1989b). Biological nitrogen cycling in the nitracline. Limnol Oceanogr 34: 493-513.

Ward BB, Zafiriou OC. (1988). Nitrification and nitric oxide in the oxygen minimum of the eastern tropical North Pacific. Deep Sea Res A 35: 1127-1142. 
Woebken D, Fuchs BM, Kuypers MMM, Amann R. (2007). Potential interactions of particle-associated anammox bacteria with bacterial and archaeal partners in the Namibian upwelling system. Appl Environ Microbiol 73: 4648-4657.
Wright JJ, Konwar KM, Hallam SJ. (2012). Microbial ecology of expanding oxygen minimum zones. Nat Rev Micro 10: 381-394.

Yool A, Martin AP, Fernandez C, Clark DR. (2007). The significance of nitrification for oceanic new production. Nature 447: 999-1002.

Supplementary Information accompanies this paper on The ISME Journal website (http://www.nature.com/ismej) 